\title{
Female Directors on Corporate Boards: Does Female Leadership Drive Corporate Environmental Transparency?
}

\author{
Michelle Siew Huei Phua ${ }^{1 *}$, and Poh-Ling $\mathrm{Ho}^{1}$ \\ ${ }^{1}$ Curtin University, Sarawak, Malaysia
}

\begin{abstract}
This paper examines the role of female directors on corporate boardroom on the extent of corporate environmental disclosure (CED) of 260 Malaysian listed companies in year 2013. Resource dependence theory is utilized as the theoretical framework to explain the role of female directors on corporate boards. Content analysis is employed to gauge the extent of CED based on a self-constructed index that is derived from Global Reporting Initiatives (GRI) and prior studies. Multiple regression is conducted and findings revealed that female directors' presence and female holding multiple directorships to be significant predictors of extent of CED. The findings lend support to the resource dependence theory on the contribution of board gender diversity and are useful for both policy makers and regulators.
\end{abstract}

\section{Introduction}

Gender equality in corporate boardrooms has been a topic of corporate governance discussions around the world. When Norway first introduced gender quota on its OSElisted Norwegian companies in year 2005, the move has raised discussions among leaders of the corporate world and academics on female leadership roles [1]. Several countries have since encouraged corporate boardroom gender diversity to diversify the memberships of a board. In a similar move, Malaysia became the first country in the Asia Pacific region to introduce a board gender quota in year 2011.

The board of directors of a firm play important roles in determining a firm's strategic directions and disclosure decisions [2]. Women make up of at least half of the human capital in any nation. By including women into corporate boardrooms, it enables firms to tap into a pool of talent which women can contribute. According to [3], a heterogeneous group of decision makers can enhance competitiveness of a firm in an industry and produce effective decisions for a firm as the inclusion of non-traditional members in a board can tackle the issue of group-think that normally happens in a homogeneous board. Worldwide, there has been constant increasing interest on the issue of environmental sustainability. Pressure from various stakeholders has pushed corporations around the world to embed environmental sustainability practices into their day to day business operations. Investors have shifted from evaluating solely the financial performance of a firm to include non-

\footnotetext{
*Corresponding author: michelle.phua@curtin.edu.my
} 
financial performance to gauge a firm's long term value creation $[4,5]$. The inclusion of women directors can broaden the perspective of a board of directors to facilitate decision making and respond to demands of a diverse group of stakeholders. Prior studies have shown that corporate board gender diversity is positively associated with the extent of sustainability disclosure of firms in developed countries $[1,6]$. Hence, this paper focuses on the role of female directors in corporate decision making through the lens of environmental reporting by Malaysian listed companies in year 2013.

The resource dependency theory is used as the framework to explain the inclusion of women into corporate boards. By having diversity in boardrooms, firms can tap into more resources such as having more external networks, different sets of skills, expertise and experiences of female directors which adds value to the firm. The content analysis method is employed to gauge the extent of environmental disclosure by 260 Malaysian firms listed on the Bursa Malaysia stock exchange and multiple regression analysis is carried out to examine the association between corporate board gender diversity and extent of environmental disclosure by the listed firms.

This study finds that the presence of female directors on corporate boardrooms and female directors with multiple directorships are significant predictors of environmental disclosure practices of Malaysian listed firms. The result provides support to the role played by female directors in providing essential resources such as advice, counsel and outlook to firms. These results are of significance to policy makers and regulators to further encourage participation of women in corporate decision making positions.

This study contributes to the body of literature on corporate governance in terms of board gender diversity. First, it provides important insights into the roles played by female directors in Malaysia, a developing country, where board memberships are normally dominated by males. Secondly, a study on the association of board gender diversity and voluntary environmental disclosures provides rich insights into the contribution made by female directors on corporate boards in terms of sustainability issues. Finally, as the Malaysian government has advocated the importance of having board gender diversity and environmental sustainability, the examination of such board compositions and disclosure practices can assist policy makers to deliberate their future policy-making decisions.

The rest of the paper is structured as follows. Section 2 provides the literature review into the development of women in Malaysia and hypotheses developed to examine female roles in corporate decision. Section 3 gives the research methodology and the results of this study are presented in Section 4. Section 5 concludes the paper.

\section{Literature review and hypotheses development}

Following the initiative taken by Norway in mandating gender quota in Norwegian corporate boards, Malaysia too joined the bandwagon by enacting a policy target through its Securities Commission Corporate Governance Blueprint in 2011. This authoritative document advocates women in decision making positions through a recommendation for public listed companies to achieve $30 \%$ female representation in corporate boardrooms by year 2016.

In today corporate world where culture, political and societal views and values are constantly changing and evolving, it is crucial for a firm to be able to manage its business risks and environmental challenges in order to satisfy a wide range of stakeholders. This could be achieved by having an effective board as strategic directions are made at the board level and influences the actions taken by management which in turn affects both shareholders and stakeholders. Hence, an effective board is needed for corporate management to better respond to demands from various stakeholder groups. 
Resource dependency theory provides an ideal framework to explain the need to include female directors on corporate boardrooms. This theory posits that an organization has to draw crucial and critical resources in order to better meet the demands of the society which will ensure the legitimacy of a company. The board of directors has several functions in an organization which includes monitoring and controlling management's decisions, providing useful information and counsel to the management; ensuring management complies to applicable laws and regulations pertaining to the firm and providing beneficial linkage to their external environment [7]. By having heterogeneous boards, the diversity of memberships in a board enable firms to address specific issues faced by different stakeholder groups and respond to such demands accordingly. Also, by having female directors on corporate boardrooms, a board can better manage and monitor management as female directors normally will bring different sets of skills, experience and expertise which can help to enhance the governance of a corporate board. Board gender diversity are evidenced to provide critical external resources to a firm as the involvement of female directors in decision making positions contribute valuable insights to management, unique perspectives into setting corporate strategy and enhancing corporate reputation in the society [8].

The impact of corporate board gender diversity on environmental sustainability of a firm should not be overlooked. Prior studies found that presence of female directors in corporate board enhanced the level of environmental awareness of a company [9]. According to Park, Choi [10], female directors are more environmentally conscious than their male counterparts and are generally more sensitive towards environmental exploitations issues that happened in the society. Galbreath [11] however documented a different conclusion regarding female directors' contribution towards environmental disclosure in U.S. firms. Hence, in order to examine the association between the presence of female directors on corporate boards on the extent of corporate environmental disclosure, the following hypothesis is developed:

$\mathbf{H}_{1}$ : There is a positive association between presence of female directors on corporate boards and the extent of corporate environmental disclosure by Malaysian listed firms.

The contribution of female directors' influence on corporate decision making can also be evaluated through the number of directorships held by the female director. By holding multiple directorships of different firms, a female director can acquire knowledge on best practices in the industry and can provide this crucial resource to help management better understand the society it operates in. It enables the sharing of timely and relevant information across firms. Previous studies found that interlocked firms practiced similar corporate strategies [12]. In order to formally test the association between the two variables, the following hypothesis is developed:

$\mathbf{H}_{2}$ : There is a positive association between female directors with multiple directorships and the extent of corporate environmental disclosure by Malaysian listed firms.

Board independence is a core to good corporate governance of a board. Independent non-executive directors exist in corporate boards to function as a check and balance mechanism to ensure that decisions made by the board as a whole and management is congruent with the interest of the owners of the firm [13]. Malaysia Code on Corporate Governance 2012 has emphasized on the importance of environmental sustainability in making corporate decisions as it affects both shareholders and stakeholders. In order to test the association between board independence and the extent of corporate environmental disclosure, the following hypothesis is tested:

$\mathbf{H}_{3}$ : There is a positive association between independent non-executive female directors and the extent of corporate environmental disclosures by Malaysian listed firms.

Audit committee is where corporate accounting policies as well as corporate disclosure policies decisions are made. Hence, another way to gauge influence of female directors on 
corporate reporting is to examine female involvement in corporate board audit committees. Several studies found that female directors are normally seated in board audit committees perhaps due to their sensitive nature towards the needs of stakeholders and community around them [14]. To formally examine the association between female directors on board audit committee and the extent of corporate environmental disclosure, the following hypothesis is developed:

$\mathbf{H}_{4}$ : There is a positive association between female directors seated on board audit committee and the extent of corporate environmental disclosure of Malaysian listed firms.

\section{Data and methodology}

\subsection{Sample source and variables operationalization}

The data of this study is taken from the annual reports of 260 non-financial quoted Malaysian companies with financial years ending during 2013. Year 2013 is chosen for the analysis as it is timely to evaluate public companies' respond to the Corporate Governance Blueprint 2011 to include female directors on corporate boardrooms. The dependent variable in this study is the extent of corporate environmental disclosure (CED) by Malaysian listed firms. A researcher-constructed index of 18 items is utilized as a proxy to gauge the extent of environmental disclosure by Malaysian firms. The index is derived from the Global Reporting Initiatives (GRI) to ensure content validity as it is the most authoritative source of corporate social and environmental responsibility reporting globally. Independent variables included in this paper are presence of female directors in corporate boards (FemDir), female directors holding multiple directorships (FemMD), female directors as independent non-executive directors (FemINED) and female directors seated on board audit committee (FemBAC). Variables which are found to be determinants of CED in prior studies are included in this paper as control variables. These variables are firm size (Size), profitability (RoA), leverage (Lev), ownership concentration (OwnerConc), auditors' quality (Big4) and industry membership (Ind).

\subsection{Multiple regression model}

To test the association between the dependent variable with independent variables and control variables included in the study, the following Ordinary Least Square (OLS) regression with robust standard errors on a basis of cross-sectional analysis is developed:

$$
\begin{gathered}
C E D_{x}=\beta_{0}+\beta_{1} \text { FemDir }+\beta_{2} \text { FemMD }+\beta_{3} \text { FemINED }+\beta_{4} \text { FemBAC }+\beta_{5} \text { OwnerConc } \\
+\beta_{6} \text { Big } 4+\beta_{7} \text { RoA }+\beta_{8} \text { Lev }+\beta_{9} \text { Ind }+\beta_{10} \text { Size }+\varepsilon_{x}
\end{gathered}
$$

\section{Results and discussions}

Table 1 summarizes the multiple regression results based on the model developed. The hierarchical multiple regression technique is used in this study in order to control for the confounding effects by control variables identified in the study. When only control variables used in the study is entered, the explanatory power of the model as indicated by the value of adjusted $\mathrm{R}$-square is $21.6 \%$. The second multiple regression is run with both independent and control variables entered and the explanatory power of the model has improved with the adjusted R-square of $28.80 \%$. The model is highly significant $(p<0.01)$ suggesting that the model explains a substantial percentage of the variation in the level of environmental disclosure. 
Table 1: Summary of Multiple Regression Results

\begin{tabular}{|c|c|c|c|c|c|c|c|}
\hline \multirow[b]{2}{*}{ Model } & \multirow{2}{*}{$\begin{array}{l}\text { Adjusted R } \\
\text { Square }\end{array}$} & \multirow{2}{*}{$\begin{array}{l}\text { Std. Error } \\
\text { of the } \\
\text { Estimate }\end{array}$} & \multicolumn{5}{|c|}{ Change Statistics } \\
\hline & & & $\begin{array}{l}\text { R Square } \\
\text { Change }\end{array}$ & F Change & df1 & df2 & $\begin{array}{c}\text { Sig. F } \\
\text { Change }\end{array}$ \\
\hline $\begin{array}{c}\text { Control } \\
\text { variables } \\
\text { only }\end{array}$ & .216 & .20024 & .234 & 12.884 & 6 & 253 & .000 \\
\hline $\begin{array}{c}\text { Independent } \\
\text { and control } \\
\text { variables }\end{array}$ & .288 & .19084 & .081 & 7.390 & 4 & 249 & .000 \\
\hline
\end{tabular}

$\mathrm{H}_{1}$ proposes a positive association between female directors in corporate boardroom and the extent of environmental disclosure practices. Table 2 reveals a positive and statistically significant association between CED and female directors on corporate boardroom $(p<0.10)$, suggesting that the presence of female directors engender greater environmental disclosure. Hence, $\mathrm{H}_{1}$ is supported. The result of this study provide evidence that female directors can bring valuable resources to a company by influencing management to be more environmentally sustainable by having environmental-friendly practices and providing more environmental information to the public.

$\mathrm{H}_{2}$ proposes a positive association between female directors holding multiple directorships and the extent of environmental disclosure practices by Malaysian listed companies. $\mathrm{H}_{2}$ is supported by the results shown in Table 2 as there is a positive and statistically significant association between a firm's CED and female director holding multiple directorships $(\mathrm{p}<0.01)$.

Table 2: Multiple Regression Results

\begin{tabular}{|c|c|c|c|c|c|}
\hline \multirow{2}{*}{ Model } & \multicolumn{2}{|c|}{$\begin{array}{c}\text { Unstandardized } \\
\text { Coefficients }\end{array}$} & $\begin{array}{c}\text { Standardized } \\
\text { Coefficients }\end{array}$ & \multirow{2}{*}{$\mathrm{t}$} & \multirow{2}{*}{ Sig. } \\
\cline { 2 - 4 } & $\mathrm{B}$ & Std. Error & Beta & & \\
\hline (Constant) & -.691 & .183 & & -3.777 & $.000^{* * *}$ \\
\hline FemDir & .236 & .152 & .121 & 1.554 & $.060^{*}$ \\
\hline FemMD & .498 & .191 & .194 & 2.602 & $.005^{* * *}$ \\
\hline FemINED & .118 & .285 & .038 & .415 & .339 \\
\hline FemBAC & -.025 & .301 & -.006 & -.084 & .467 \\
\hline OwnCon & .090 & .075 & .066 & 1.212 & .113 \\
\hline RoA & .004 & .063 & .006 & .066 & .474 \\
\hline Leverage & .059 & .057 & .099 & 1.034 & .151 \\
\hline Industry & .012 & .032 & .021 & .385 & .350 \\
\hline Big4 & .062 & .026 & .136 & 2.364 & .009 \\
\hline NLogTotalAsset & .042 & .010 & .278 & 4.283 & .000 \\
\hline
\end{tabular}

Legend: The independent variables are FemDir $=$ female directors; FemMD $=$ female directors with multiple directorships; FemINED $=$ female directors as independent non-executive directors; and FemBAC $=$ female directors in board audit committee. The control variables are OwnCon=ownership concentration; RoA=return on assets; Lev=leverage; Industry= industry membership; Big4= auditor's quality; LgTotalAsset=log of total assets. Associations $* * *$ and $* * *$ are statistically significant at the $10 \%, 5 \%$ and $1 \%$ respectively.

Although the association between the extent of CED and female directors as independent non-executive directors in corporate boardroom is positive, this association does not reach statistical significance. Hence, $\mathrm{H}_{3}$ is rejected. This may be due to the lack of experience and knowledge of independent non-executive directors on environmental issues. 
The influence of independent directors on environmental reporting may be limited as they are not directly involved with the daily operations of the organizations.

$\mathrm{H}_{4}$ proposes a positive association between female directors as board audit committee members and the extent of environmental disclosure practices by Malaysian listed companies. However, $\mathrm{H}_{4}$ is, not supported by the results in Table 1 as there is no statistical significance. This could be attributed to the fact that more focus is being directed to the financial risk of a firm, rather than environmental issues facing the firm.

This study also includes control variables to control for any confounding effects they may have on the results of the study. Of the six control variables incorporated, only firm size and auditor's quality are found to have positive and statistically significant impact on CED at $\mathrm{p}<0.01$ level. The results suggest that big firms and Big 4 auditors drives environmental transparency.

\section{Conclusions}

Using a sample of 260 Malaysian listed companies, this paper examines the role of female directors in corporate decision making through the lens of environmental reporting by Malaysian listed companies in year 2013. The multiple regression results indicate that female directors in a boardroom and female directors holding multiple directorships are positively and significantly associated to the extent of CED of Malaysian companies. The findings of this paper highlights the importance of the role played by female directors in providing valuable resources to a company by influencing management to communicate environmental practices of the companies to the public through annual reports. This lends support to the resource dependency theory on the contribution of corporate board gender diversity in a company.

The results of this study provide valuable knowledge and fresh insights into role of female directors and environmental disclosure practices of Malaysian listed companies. Policy makers and regulatory bodies may benefit from the findings of this paper to encourage more active participation of female in corporate decision making positions. Future research can consider examining the impact of the presence of female directors on the overall CSR dimensions and taking into account information disclosed on other medium of reporting such as press releases, media and company's website to have a thorough picture of a company's disclosure practices.

\section{References}

1. R. Labelle, C. Francoeur, F. Lakhal, Gend Work Organ, 22, 4 (2015)

2. O. Bohren, R. Strom, J Bus Finan Account, 37, 9/10 (2010)

3. W. Amar, M. Chang, P. McIllkenny, J Bus Ethics 129, 3 (2015)

4. J. Cowton, S. Sandberg, Encyclopedia of Applied Ethics $2^{\text {nd }}$ ed (2012)

5. A. Haji, M. Anifowose, SAMPJ, 7, 2 (2016)

6. M. Larkin, A. Benardi, M. Bosco, Account Publ Interest, 13, 1 (2013)

7. E. Landry, A. Benardi, M. Bosco, Corp Soc Resp Env Ma, 23, 1 (2016)

8. D. Seto-Pamies, Corp Soc Resp Env Ma, 22, 6 (2015)

9. L. Liao, L. Luo, Q. Tang, Br. Account. Rev., 47, 4 (2014)

10. S. Park, S. Choi, E. Kim, Corp Soc Resp Env Ma, 19, 6 (2012)

11. J. Galbreath, Bus Strat Environ 19, 5 (2010)

12. T. Lambooy, Crit Studies Corp Resp Gov Sust, 1 (2010)

13. A. Haji, MAJ, 28, 4 (2013)

14. T. Hafsi, G. Turgut, J Bus Ethics, 112, 3 (2013) 